\title{
New Religious-Nationalist Trends among Jewish Settlers in the Halutza Sands
}

\author{
Hayim Katsman ${ }^{1}$
}

\begin{abstract}
This article describes the religious worldview of the residents of three rural villages, established since 2010 in Southern Israel. Focusing on religious authority, the article traces the complex relationship between rabbis to their communities which is rarely a simple "top-down" traditional authority model. On the contrary, both the rabbis and their communities are aware of the fragility of their relationship, and therefore created a complex belief system in which the rabbis' recommendation is sought, but not necessarily considered binding. In addition, the article describes the "Datlshim" (Hebrew acronym for "Ex-religious"). This liminal identity characterizes individuals who grew up within these religious communities but decided to dissent in their adulthood. They do not feel committed to, and sometimes openly reject the Jewish religious code. The article contributes to the scholarly understanding of religious authority, as well as the diversity within the religious-Zionist community in Israel, which bas become increasingly influential is Israeli politics and society.
\end{abstract}

Keywords: Israel; religion; religious authority; religious-Zionism; secularization; religionization.

\section{Introduction}

The young religious family that wanted to move to a village in southern Israel had no intention to provoke such a controversy. Indeed, all members of the village selection committee shared the impression that the family was friendly and showed genuine commitment to village values. However, some committee members were concerned by the fact that the wife's nose was pierced. While nose piercing is permitted according to Halacha (Jewish religious code), it is not socially acceptable among the more conservative Orthodox circles. The committee could not reach an agreement. They decided to consult with the village rabbi, who ruled that they can accept the family. Nevertheless, some members were still not convinced. As a final resort, they took the issue to their top rabbinic authority, the head of the prestigious "Har HaMor" Yeshiva, with which many of the village members are affiliated. The rabbi listened to both sides, and eventually also ruled that they can accept the family. The opposers started arguing with him, questioning the ruling of their own ultimate religious authority, but the rabbi was steadfast. Eventually, the committee decided to reject the family.

This incident, which was described to me by members of one religious community in which I was interviewing, demonstrates one of the oldest problems in the study of religion. In the Platonic dialogue "Euthyphro," Socrates searches for the definition of 'the holy/pious' [ö Euthyphro's attempt to define the pious as 'what is loved by the Gods,' Socrates asks: "Is the pious being loved by the gods because it is pious, or is it pious because it is being loved by the gods?" 1 Hayim Katsman, Henry M. Jackson School of International Studies, University of Washington, United States. E-mail:
hkatsman@gmail.com 
(Plato, 2002, p. 12). In other words, is the conception of holiness arbitrary, simply denoting what the gods (represented by religious authority) have defined as 'holy'? Or perhaps is holiness that which we human beings decide through a social process?

Similar debates appear also in the Jewish tradition already in the $5^{\text {th }}$ century Babylonian Talmud, ${ }^{2}$ and Modern theorists of religion still seem to be struggling with Euthyphro's dilemma. The foundational thinkers of the social sciences gravitated towards one side of Euthyphro's dilemma. Rooted in modernity and secularization, they viewed religion as a social construct. Endorsing the scientific method as their epistemological framework, Durkheim (1915) defined religion as a system of social knowledge, and Geertz saw religion as merely a "system of symbols... formulating conceptions of a general order of existence" (cited in Asad, 1993, p. 29). Later thinkers, such as Asad and Mahmood, problematized that notion from the other side of Euthyphro's dilemma. They emphasized the importance of adherence to religious rites as a precondition for constituting the knowledge within the believer (Mahmood, 2005; Asad, 1993).

\section{Religion in Israel}

Understanding the different approaches to Euthyphro's dilemma sheds light on the ongoing debates regarding the public role of religion and religious authority. Religion has fascinated sociologists since the emergence of the social sciences as an academic discipline, and there are ongoing debates regarding secularization and the changing role of religion in the public sphere (Casanova, 1994; Butler et. al, 2011). However, as Casanova famously states: "There is no consensus, perhaps there will never be, as to what counts as religion" (Casanova, 1994, p. 26). Therefore, it is necessary to "unpack" what it is we talk about when we talk about religion.

The problem of understanding social processes of secularization and religionization magnifies in Israel, where the Jewish religion serves as a strong force in civil religion and national legitimation (Liebman \& Don-Yehiya, 1983; Abulof, 2014). A mix of ideological, political, and practical considerations kept religion as a strong force in the Israeli public sphere (Kimmerling, 2001; Katsman and Ben-Porat, 2019). Despite the inability to separate religion and state in Israel, the Israeli Labor movement was able to create a secular hegemony, in which the public role of religion was limited to certain domains. However, the gradual decline of the Labor-Zionist secular hegemony since 1977 has created anxiety among the secular public from the increasing social and political influence of the religious-Zionist movement. This anxiety has intensified over the last decade. Maniv \& Benziman noted the rapid increase in public discussions of "religionization" [Hadatab] in Israeli media during the 2010s, pointing to an increase of $1000 \%$ in the use of the term over just three years (Maniv \& Benziman, 2020).

Following the public debate, there are some attempts by researchers of Israel to account for this phenomenon and analyze different modes of religionization in Israeli society. In 2012 the Israel Studies Review published a roundtable discussion on the subject, in which scholars presented the empirical evidence for the phenomenon (Israel Studies Review, 2012). Israeli sociologist Yagil Levy went even further, arguing that the Israeli military has undergone a process of 'theocratization,' in which military orders are being subjected to religious authority (Levy, 2014; 2015). Recently, Yoav Peled \& Horit Herman-Peled published a comprehensive account of religionization processes in Israeli society (Peled \& Herman-Peled, 2019). In their book, they provide an elaborate historical analysis of the

\footnotetext{
2 The discussion on "The Oven of 'Akhnai" (Bava Metzia, 59a-b) is probably the most well-known example.
} 
process, as well as demonstrating how almost every domain of the Israeli society has been affected by religionization.

In contrast to this body of work, Guy Ben-Porat argues that the Israeli society has actually been secularizing since the 1990s. Ben-Porat does not deny the increasing public role of Judaism in Israel, but rather makes an analytical distinction between 'secularism' as an ideology and 'secularization' as a social phenomenon. Following Mark Chaves (1994), Ben-Porat defines secularization as "the decline of religious authority and challenges to existing religious institutions" (Ben-Porat, 2013, p. 12). Applying Joel Migdal's state-in-society approach (Migdal, 2001), he traces these developments that took place not as official state policies but rather as the result of individuals' decisions frequently based on economic considerations. Focusing on four issues - Regulation on marriage, civil burial, the ban on selling pork, and commerce on the Sabbath, Ben-Porat demonstrates that religious authority is in-fact declining and an increasing number of Israelis are choosing are ignoring, and in some cases actively opposing, traditional religious authorities (Ben-Porat, 2013).

How can we reconcile these two opposing views? Is it possible that Israel is religionizing despite the decline of religious authority? Most authors point to the religious-Zionist sector as the primary agent of religionization in the Israeli society (Peled \& Herman-Peled, 2019; Levy, 2015; Maniv \& Benziman, 2020). However, my research on the religious-Zionist community in Israel reveals a more complex picture. On the one hand, as I will demonstrate in this article, religious authority is indeed in decline, and dissent is visible even among the most conservative religious-Zionist circles. On the other hand, this does not necessarily mean that individuals are undergoing "secularization." Returning to the anecdote of the family with the nose-pierced woman, we can see that a religious consideration could be used in order to reject a more traditional religious authority. However, as Euthyphro's dilemma teaches us, this is not necessarily "secularization," but rather a different understanding of what religion is.

In the next sections, I will describe some findings from fieldwork carried out within three conservative religious-Zionist communities, recently established in the southern Israeli desert. I will present the unique context of their establishment, which gives us an insight into the different trends of contemporary religious settlements in Israel. ${ }^{3}$ I will then go on to present my findings on the various approaches to religious authority among the village members, which will then shed light on the debate regarding secularization and religious authority.

\section{Historical and organizational background}

On July 15th 2001, Israeli prime minister Ariel Sharon brought to the cabinet a governmental decision announcing a plan to establish five new villages in the Halutza sands. The primary objective behind this decision was an attempt to prevent the evacuation of these lands as part of a future peace agreement between Israel and the Palestinians. The Halutza sands are within the 1967 borders, but due to their proximity to the Gaza strip the Israeli representatives in the "Geneva Initiative" negotiations intended them for a "land swap" in exchange for the settlement blocs in the West Bank. ${ }^{4}$

\footnotetext{
${ }^{3}$ Since 1967 , the settlement efforts of the religious-Zionist community focused primarily on establishing settlements in the lands occupied during the 1967 war. The settlements described in this are unique since they were established within the "Green Line," i.e. within the state of Israel and not within the Occupied Palestinian Territories.

4 The Palestinians rejected this proposal during the negotiations, arguing that it is desert land. The final Geneva Initiative document does not include the Halutza sands in the areas intended for land swap (Klein, 2006).
} 
The blunt political incentive behind this decision raised opposition from left-leaning MKs. Those wondered why the government does not allocate these funds to strengthen the existing desert dwellers. According to MK Taleb al-San'a, this decision is not only meant to prevent peace but rather also an attempt to 'Judaize' the space. Al-San'a mentioned the struggle of the Al-'Azame Bedouin tribe which has requested to establish a permanent village in that area, in order to resettle a village they were evacuated from in the 1948 war. In the past, he says, the government objected the establishment of a new village in the Halutza sands for 'security concerns,' claiming the area was a military 'firing zone.' "When the government wants to establish a Jewish settlement, the firing zones are annulled immediately," said al-San'a bitterly. ${ }^{5}$

Government offices moved on in the planning and zoning of the villages despite the political opposition, yet it was unclear who would eventually live there. Discussing this plan in his 2003 book, Israeli geographer Elisha Efrat wrote that "there is a doubt if the Halutza sands could provide the infrastructure for massive settlement ... it seems, that settlement in that area is a futile and pointless step" (Efrat, 2003, p. 99). Indeed, for years the government was not successful in attracting people to settle the villages. The solution came eventually only in 2005, just after Ariel Sharon completed his plan to evacuate 8,000 Jewish settlers who lived within the densely populated Palestinian Gaza Strip, known as the "disengagement plan." Two of the uprooted communities reached an agreement with Sharon to settle in the planned villages. The same people who were evacuated from their homes in Gaza by the decision of Ariel Sharon were also those who went on to materialize his vision of settlement in the Halutza sands. The irony in this development did not go unnoticed. On the contrary, many residents find pride in this.

Today, there are three thriving religious communities in the Halutza sands. While all three communities are religious-Zionist, each has unique characteristics. The variation is a result of the different historical trajectories of their establishment, and they preserve their cultural difference through a vetting process for new members. The villages also vary in their formal organization structure: Naveh and Bnei-Netzarim were established as a "Moshav" and Shlomit is officially a "community settlement" [Yishuv Kehilati].

Originally, the idea of moshav was conceived in the 1920s as a smallholders' cooperative community. In accordance with the Socialist-Zionist ideology, the moshav was based on communal values. The agricultural land is collectively owned by the moshav, but each household is considered an independent economic unit and entitled to an equal share of the land which it is expected to cultivate. Due to government economic policies and a general decline in agricultural income, today residents in moshavim hold various occupations and most of them lease their agricultural land to larger farms (Sofer \& Applebaum, 2006). ${ }^{6}$

A "community village" is a newer type of settlement, which was conceived and developed under the right-wing "Herut" government after 1977 in order to settle the West Bank. As a result, the community settlement is based on liberal-individualistic values and usually has no agricultural lands and no collective ownership. Nonetheless, despite the different economic models, both community types have a general assembly, an executive board, and committees which enable them to democratically reach collective decisions and preserve the sense of a community. Perhaps most

\footnotetext{
${ }^{5}$ http://knesset.gov.il/tql/knesset_new/knesset15/HTML_28_03_2012_09-20-03-AM/20010718@225-01JUL18@047.html

${ }^{6}$ Since the residents of the Moshav received the land in order to cultivate it, leasing it is formally illegal. However, it is a known secret and in most cases the state turns a blind eye towards this violation as long as the land is not used for purposes other than agriculture.
} 
importantly, these communities have an "absorption committee" [va'adat Klita], which is intended to preserve social homogeneity within the community by vetting potential members (Newman, 1984).

Naveh

The settlement of 'Atzmona was initially established in 1979 in Sinai, as a protest against the CampDavid accords. ${ }^{7}$ In 1982 the Israeli government evacuated 'Atzmona's residents and resettled them in the Gaza Strip. In 2005, just before the evacuation of all Jewish settlements in Gaza ('Gush Katif'), some settlers from 'Atzmona reached a secret agreement with the government. ${ }^{8}$ According to the agreement, they were to evacuate their village peacefully and would be given the opportunity to reestablish their community in one of the intended villages in the Halutza sands. ${ }^{9}$ After the evacuation there was a split within the community - 65 families established a protest city of tents near the Southern city Netivot and eventually agreed to settle in Shomriya, closer to Israel's center. A smaller group, approximately 30 families, moved to temporary housing in Yated in order to prepare for their move to the future village nearby in Halutza. At the time, they say, there was nothing in Halutza. The road just came to an end and all you could see was sand. Only after four years of intensive development was the village ready for the initial families to move in.

Since 'Atzmona's rabbi moved to Shomriya, the remaining community was in search of a spiritual leader. During the period in Yated, they asked Rabbi Mordechai (Motti) Hass, head of a religious institution in the West Bank settlement Elli and a close disciple of Rabbi Zvi Tau (head of "Har HaMor" yeshiva in Jerusalem), to be the spiritual leader of their community. Rabbi Hass had a unique vision for the creation of an ideal ultra-religious-Zionist community in light of rabbi Kook's theology, and he moved to Yated with a group of his followers from Elli with the intent to materialize it. Very soon, the original settlers from 'Atzmona stepped aside from the leadership (some left Naveh), and rabbi Hass and his followers became the dominant figures in the community's leadership.

Naveh is a moshav of approximately 130 households. ${ }^{10}$ There is a consensus among residents in the area that it is the most religiously conservative among the three villages. ${ }^{11}$ Unlike most residents in the other villages (and in the religious-Zionist community in general), all of my male interviewees from Naveh undertook extensive religious studies in a yeshiva, at least into their late $20 \mathrm{~s}$. The majority of them studied in "institutions of the line" [Yeshivot HaKav]. ${ }^{12}$ Although it is formally registered as a moshav, its economic structure is intended to support the residents' Torah learning and therefore deviates from the standard model. Above all, the agricultural lands are not allocated to the residents, but rather held and cultivated by a communal agricultural association. The village's collective agricultural association employs workers, some of them from the village, to manage the collective

\footnotetext{
7 On 17 September, 1978, Israel and Egypt signed a peace agreement. According to the agreement, Israel was to withdraw its troops and evacuate all settlements from the Sinai Peninsula, which it occupied from Egypt during the 1967 war.

${ }^{8}$ This is a sensitive issue among the evacuees, and I have heard various stories about it. Some people deny that an agreement was reached before the evacuation.

${ }^{9}$ Some people told me that it was the farmers from the village who pushed to accept this agreement since they already had agricultural land in the area.

${ }^{10}$ Eventually, it is planned to reach 350 households.

${ }^{11}$ Some even say it is the most conservative religious-Zionist community nationwide.

12 "The line" refers to a specific tone within the Hardal subculture, which follows Rabbi Tau. The most notable institution of "the line" is Tau's Har HaMor Yeshiva, and the yeshivas in Mitzpe Ramon and Hebron are also affiliated with "the line." The name comes from the ideological rigidness in the institutions, which requires students to adhere to Rabbi Tau's ideological "line."
} 
property and cultivate the lands. This arrangement does not necessarily stem from an egalitarian worldview but rather in order to enable most residents to focus on the study and teaching of the Torah. To that end, Naveh runs a network of religious educational institutions, most notably the "Otzem" Mechina (pre-military preparatory institution). "Otzem" was initially established in Atzmona by Israel's former Minister of Education, Rabbi Rafi Peretz, who currently lives in Naveh. The Mechina is considered prestigious among religious-Zionist circles and draws religious youngsters who want to strengthen their religious identity prior to enlistment. In addition, in Naveh, there are two religious elementary schools and two high schools (separate institutions for boys and girls), as well as an intensive-study yeshiva for high school graduates. All educational institutions are privately funded and are therefore not subjected to curriculum requirements of the Ministry of Education. ${ }^{13}$ Most institutions are not yet economically self-sustainable and are funded by the village's economic revenues and donations. Many members of the community are employed in these institutions. Private entrepreneurship is not common in the village.

\section{Bnei-Netzarim}

Similarly, Bnei-Netzarim was also established as a result of a split within a community of evacuees from Gush Katif in the Gaza Strip. Netzarim was initially established in 1972 as a military base in the outskirts of Gaza city and was populated by temporary groups. The Jewish enclave later changed to a religious Kibbutz (communal agricultural community) in 1984, but was not able to attract many families who would bear the risk of living in the area. Finally, in the early 1990s, a group of students from Merkaz Harav yeshiva joined, and the Kibbutz turned into a community settlement in 1992. After the Oslo agreements, Netzarim was completely isolated from the other Jewish settlements in Gaza, and travel to or from the village required an armored military convoy. ${ }^{14}$ The settlers of Netzarim refused to negotiate with the government before the 2005 evacuation, hoping that the plan would not be executed. Therefore, they had no living arrangements after the evacuation and were placed temporarily in the students' housing of the Ariel College in the West Bank. While in Ariel, a debate emerged within the community. Learning about the plans of their friends from 'Atzmona to establish new settlements in Halutza, some wanted to join them, while others preferred to stay in Ariel. This debate tore the community apart and they decided to have a vote, resulting in only a slight majority of those who wanted to move to Halutza. Therefore, the community sadly decided to split, allowing each household to decide individually if it wanted to stay in Ariel or move to Halutza and establish a new village.

After the decision was made, those who chose Halutza moved to temporary housing in Yevul, where they waited for their village to be built. In contrast to Naveh, the original settlers of Netzarim are still dominant in the community leadership, and they see themselves as a direct continuation of the original community in Gaza. Some residents told me that arguing for a certain policy because "that is how it was in Netzarim" is common in village assemblies. This idea of continuity is also indicated by the name of the village ("Bnei-Netzarim" is Hebrew for "children of Netzarim").

\footnotetext{
${ }^{13}$ In 2011, 2013, and 2016 math proficiency tests, the boys' elementary school was ranked in the lowest decile.

14 On May 4, 1994, Israel and the Palestinians signed an agreement in which Israel would reorganize its military presence in the Gaza Strip. The new arrangement limited the Israeli military's ability to guarantee the security of drivers on the road connecting Netzarim to the other Gaza settlements. As a result, if they wanted to visit other Gaza settlements they had to leave the Gaza strip completely and enter it from the other border crossings.
} 
As of 2019, out of 45 families from Netzarim that initially moved to the Yevul, only 22 were still living in Bnei-Netzarim. All in all, approximately 130 families live in the village. ${ }^{15}$ Bnei-Netzarim is also considered to be extremely religious, but it allows more heterogeneity than Naveh. All my male interviewees from the village went to "yeshivas of the line," but only a few of them continued with their studies into their late 20s. The model in Bnei-Netzarim is closer to the original idea of the moshav, and many individuals cultivate their agricultural lands. The village's lands that were not claimed by individual farmers are leased to large agriculture companies by the village's collective agricultural association, which generates revenues for the community. My impression was that the majority of members in Bnei-Netzarim are teachers, entrepreneurs, or college-educated professionals. A small minority receive a stipend for full-time studying of the Torah. Today, individuals who want to join the village and claim agricultural land must go through a trial period. The village allows them to rent their land for two years and provides them with training and mentorship. After this trial period, the new members can claim their land permanently and officially join the agricultural association. The logic behind this system, as was explained to me by members, is that the village wants to avoid the sight of abandoned greenhouses, which became common in many moshavim.

Similar to Naveh, Bnei-Netzarim operates several educational institutions. All these educational institutions are supported by the village but also rely heavily on Zionist donors' money. The village does not accept donations from Christian organizations. ${ }^{16}$ Compared to Naveh, it is more common to see signs thanking donors across the village. Unlike Naveh, however, in Bnei-Netzarim the genderseparated elementary schools are public. Therefore, they are required to accept religious students from all the surrounding villages, and the curriculum is subjected to the Ministry of Education's requirements. A private men-only religious high school with dormitories [Yeshiva-Tichonit] also operates in the village, in which students work in agriculture for half a day and study (mostly religious studies) for the rest of the day. Like Naveh, in Bnei-Netzarim there is a yeshiva for high school graduates. Other than the; educational institutions, the village operates a guest house for conferences and workshops. Within the village, there is also a large regional health clinic, a privately-owned small grocery store, a yoga studio, and some small businesses.

Naveh and Bnei-Netzarim partner in some economic initiatives, most notably they both hold shares in one of the largest solar-energy fields in Israel. This investment generates a stable revenue for both villages.

\section{Shlomit}

The third village, Shlomit, has a quite different character from Naveh and Bnei-Netzarim, and its establishment followed a unique trajectory. Shlomit was initially planned to be a small town, which will eventually populate 500 families and serve as a social and commercial center for the region. ${ }^{17}$ The state did not intentionally plan the village for a religious-Zionist community. For a long time, the state was not able to find enough people (secular or religious) who would agree to settle this undeveloped area. Eventually, the initial Gar'in (settlement group) for Shlomit consisted mostly of graduates of the "Otzem" mechina (religious pre-military preparatory institution), who were all young religious couples with one child or more. These first families moved to Shlomit only in 2011, after

\footnotetext{
${ }^{15}$ Like Naveh, also Bnei-Netzarim is planned to reach 350 households.

${ }^{16}$ A member of the community told me that once they even insisted on returning a significant donation, after retroactively finding out that it was from a Christian source.

${ }_{17}$ There are discussions of extending the village to 1500 families, but those plans have not yet been submitted.
} 
Naveh and Bnei-Netzarim were already established in their current location. ${ }^{18}$ In contrast to Naveh and Bnei-Netzarim, the people of Shlomit did not have a predetermined religious or symbolic vision for the village in their minds. Primarily, they were interested in living within a national-religious community with like-minded neighbors. At first, residents hoped that also secular Jews would join the village, but those did not show interest. Today the village is officially open to accepting couples from the entire range of the religious-Zionist spectrum, but the majority of residents turned out to be affiliated with the more conservative "Hardal" (Hebrew acronym for "national-ultra-Orthodox") subculture.

As of 2019, only 70 families lived in Shlomit. Due to the relatively low housing prices, it has been growing quickly and intensive construction was visible. The community in Shlomit is relatively younger than the neighboring villages (mostly under 35) and consists of college-educated professionals. From a religious point of view, Shlomit is the most heterogenous village among the three. All of my interviewees continued their Torah studies after high school, but many of them also served in the military for the full 3-year term. ${ }^{19}$ Being a "community village," Shlomit does not possess any agricultural land and its only source of revenue is "community taxes" paid by residents and donations. As a result, Shlomit lacks the means for independent development, and the public areas in the village are far less developed in comparison to the neighboring villages. ${ }^{20}$ Many of the roads are not paved, and only a few streets have sidewalks. Shlomit's synagogue was still in a temporary building and is the least impressive among the three villages. There is one daycare in Shlomit, but older children are educated outside of the village, mostly in the Bnei-Netzarim elementary school.

\section{Religious Authority and the Observance of Halacha}

Scholars consider the religious-Zionist sector, and even more so the conservative 'Hardal' subculture which these three communities are affiliated with, to be ideologically rigid (Herman et. al., 2014; Pfefer, 2007). However, my research finds a great ideological heterogeneity even within this subculture. What does characterize this subculture, though, is the attempt to create social boundaries of their community by presenting their ideology and actions as the only legitimate interpretation of Halacha. According to the largest survey conducted within the religious-Zionist community, 95.6\% of those who self-identify as 'Hardal' and $80.1 \%$ of 'national-religious' agreed with the statement "Commitment to Halacha is an integral part of my identity" (Beit-Hillel, 2014). Some individuals confessed to me that they are not always able to follow every commandment, but they are committed to the aspiration to do so. When they are confronted with religious disagreements within their own community, they insist that the source of disagreement is a shared desire to truly interpret God's will. Those who are not committed to Halacha face harsh social repercussions. ${ }^{21}$

But who has the authority to determine God's will? In traditional Judaism, this was the role of the rabbis. They were the community's leaders, and they guided their community also with regard to

\footnotetext{
18 https://www.ynet.co.il/articles/0,7340,L-4116115,00.html

${ }^{19}$ In the "Hesder" yeshivas most students defer their service and enlist for a shortened term of 16 months. In the "yeshivas of the line," it is common for students to defer even longer and enlist only for 6-9 months.

${ }^{20}$ This might also be a result of inadequate planning. A resident told me that the village was initially planned by an architect who used an urban neighborhood as a model and therefore lacks planned public spaces.

${ }^{21}$ One of my interviewees was forced to divorce and leave their community after they confessed that they do not consider themselves obligated to Halacha.
} 
social and political matters. This is still the case within the ultra-Orthodox society, where the sages promote the idea of "Daat Torah" [the Torah vien] (Brown, 2014). A survey conducted among religious-Zionists in 2014 found that most religious-Zionists hold that belief as well. According to the survey, $54 \%$ of religious-Zionists (and $87 \%$ of Hardal) attribute high importance to the rulings of rabbis on national-political matters (Herman et. al., 2014).

My findings, which are based on in-depth interviews, reveal a more complex picture. ${ }^{22}$ Despite their commitment to Halacha, the modern education they received brought them to adopt some of the normative claims of secularization theory. Secularization theory differentiates "the sacred" from other spheres of human activity such as economics and politics (Casanova, 1994). Accordingly, I found that religious-Zionists consider the authoritative role of the rabbi to be confined only to matters regarding the interpretation of Halacha. The rabbi may have an opinion on public matters or provide individual counseling, but his advice on these matters is not considered binding. Those who follow them unquestionably do it out of their own will. Moreover, many of the individuals openly stated that they do not always agree with, or follow, rabbis' religious rulings. This does not vary with regard to the level of religiosity but is ubiquitous across the religious-Zionist community. In many cases, those who have a stronger religious background will have enough confidence to research a matter on their own instead of asking the rabbi for guidance. However, since they do consider the rabbis' opinion on matters of Halacha as binding, in many cases they will not ask the rabbi for a religious ruling, in order to not explicitly disobey it:

I have a friend here that is a " $b a$ 'al teshuva." 23 After he became religious he lived in a "Mizrochnik" village. ${ }^{24}$ He couldn't understand their behavior - Why do they not adhere to explicit rulings of Halacha?! It took him time to understand that there are nuances. I was just speaking to him. His rabbi told him to vote for Shas (an ultra-Orthodox political party), so he is voting for Shas. I respect that, but I believe that each one of us has a mind. Just like I go to the doctor when I have a medical question, I consult a lawyer when I have a legal question, so I would ask a rabbi when I have a question about Halacha. [...] Once I ask the rabbi, though, I am obligated. That is a matter of black-and-white for me. I don't play games with Halacha. Let's take traveling abroad for example. ${ }^{25} \mathrm{My}$ wife and I now traveled abroad for the first time. I used to oppose that as an ideal. I don't anymore. Maybe I'm less idealistic. We really wanted to do it, so we did it. Now, can I tell you that it's 100\% in accordance with Halacha? I know some rabbis will say it's OK and some will say it's not. So I didn't ask. I know there are rabbis who permit - so I did it.

Growing up within the Israeli society, which since the 1980s has become more individualistic, members of these communities want to make their own decisions. They expect their rabbi to give them guidance, not authority:

In public matters, it is important that the rabbi gives a general direction, but he cannot coerce. [...] Not everything is a matter that you need to ask the rabbi about. At the beginning

\footnotetext{
22 Since my interviews took place only 5 years after both surveys, it is not likely that the opinions changed so drastically over that time period.

${ }^{23}$ A term to describe someone who was not born religious but joined the religious community later in life.

${ }^{24}$ A term used to describe "classical," non-"Hardal" religious-Zionism. Refers to the first religious-Zionist political party - the "Mizrachi."

${ }^{25}$ Most religious scholars prohibit leaving the Land of Israel for vacation.
} 
of our marriage, we had many questions about Niddah. ${ }^{26}$ My husband often went to the village rabbi and asked him. One evening the rabbi told him "come sit with me for a moment, you don't need to ask every little thing." You have Halacha books, you don't have to run and ask the rabbi. He taught him - "this is prohibited, this is not." The knowledge is yours. That is a rabbi's greatness. Not to have the people dependent on you.

Some of my interviewees said they have completely lost their faith in rabbis' counseling. One woman told me how she consulted with her rabbi about her abusive and violent husband. The rabbi suggested that she change her behavior in order to accommodate his needs and achieve domestic peace [Shlom Bayit. After several months of this not working, and the violence persisting, a friend insisted that she contact the state social services. Eventually, she got a divorce, but her husband remained in the community and she was the one forced to leave. Since then, she told me, she has lost her faith in rabbis. Another woman told me how her personal experience taught her not to rely on rabbis:

Personally I identify myself with the Hardal subculture, but with regard to my faith in religious-Zionist rabbis... let's say that I have a problem with what religious-Zionists colloquially call "faith in the sages" [Emunat Chachamim] I do not like the religious-Zionist rabbinic leadership. Every time I tried to rebuild my faith in rabbis something came and brought it down. A rabbi transgressed... Even rabbi Druckman, who I consider our rabbi, and I highly appreciate his contribution to the Israeli society. ${ }^{27}$ With one piece of advice that he gave me he was wrong. I don't 'burn' someone because of one mistake, but this experience taught me that I need to trust my own deliberation and not rely on rabbis.

I was surprised by these statements and wondered how the rabbis understand their role. Interestingly, they seem aware of these sentiments among their congregations, and they try to rule accordingly. The rabbi of one of the villages told me that he himself will not feel obligated to follow a public ruling of his own rabbi if he did not specifically request a ruling. This rabbi also described to me how he understands his role within the community:

I make a clear distinction. If I am asked about Halacha I say "this is what the Halacha says." With regard to public matters, I state my opinion as a general recommendation, try to illuminate some aspects... They recently consulted with me about the upcoming elections for village leadership. So we sat and discussed this matter. They are really interested in what I have to say, but not as a binding decision. I really try as much as possible to avoid being the one making the decision. I actually run away from this. This is also not healthy for the person asking. I believe that one's freedom of mind is important.

These findings are important since the majority of writing on religious-Zionism overemphasizes the importance of the rabbis' opinions. In some cases, scholars consider rabbinic discourse, represented in their books, public statements, and responsa, to represent the view of the religious-Zionist public (Hellinger et. al. 2018). An illustrative example of this is the debate over disobeying a military command to evacuate a Jewish village. Most religious-Zionist rabbis have ruled that a soldier must disobey an order to evacuate a Jewish settlement (Roth, 2014). In practice, though, only 63 soldiers explicitly disobeyed orders during the 2005 Gaza evacuation. In a survey conducted among religious-

\footnotetext{
${ }^{26}$ Niddah refers to a woman during menstruation, or in the period following it before the immersion in a ritual bath. During the period that a woman is considered "Niddah," any physical contact with her husband is prohibited.

${ }^{27}$ Rabbi Haim Druckman, a prominent religious-Zionist rabbi, head of the "Or-Etzion” yeshiva.
} 
Zionists in 2014, only 23\% stated that "you must disobey" an evacuation order, showing that they do not consider rabbis' ruling as binding (Herman et. al., 2014). We can conclude, therefore, that we cannot view public rabbinic rulings as representing the opinions within the religious-Zionist community. Moreover, the fact that there is a decline in religious authority does not indicate secularization. Even the most religious individuals I met presented ambivalent views regarding their rabbinic authority, without feeling that this compromises their religiosity.

\section{Datlashim - "I like the religion, not the religious people"}

In this context, it is also important to discuss a group that is frequently overlooked in research on the religious-Zionism. During my interviews, I also encountered a significant number of "Datlashim" (plural of 'Datlash' - Hebrew acronym for "ex-religious"), who are part of an increasing trend in the religious-Zionist society. According to recent research, more than half of religious-Zionists are less religious than the house they grew up in (Rosner \& Fuchs, 2018). However, socially, they cannot be excluded from the research on the religious-Zionist community (Katsman, 2020). The Datlashim I interviewed tend to reject the binary self-identification as "religious" or "secular." The Datlashim do not feel committed to, and sometimes openly reject, Halacha, though some of them still adhere to certain aspects. At the same time, they do not break ties with their community, and in most cases still identify with it ideologically (Gal-Getz, 2011). Most Datlashim in the region are young (18-28), and were raised within these communities. The children in Shlomit are still too young, so there are currently no Datlashim in the village. Naveh is not tolerant of Datlashim, and most of them prefer not to stay in the village. Therefore, all the Datlashim I interviewed were from Bnei-Netzarim. Some still lived with their families, and others moved to live and work in other secular villages in the area while maintaining a close connection with their family and village.

The Datlashim all shared feelings of resentment towards their religious leadership and the coercion they experienced within their communities during their teenage years. These feelings are mostly directed at people of the village who tried to control their physical appearance and the relations between sexes. They considered this hypocritical. They were brought up to value compassion and justice, but in the end, they felt they were judged superficially by the length of their skirts or the color of their hair.

I was a youth counselor at 'Bnei Akiva,' but eventually I quit. ${ }^{28} \mathrm{I}$ had a boyfriend from the village and I didn't want to hide and lie about it. When I started wearing pants in the village I didn't hear comments but there were constant stares. ${ }^{29}$ I once took a walk with a friend, and the next day he showed me that he got a text - "How can you hang out with this outcast girl?" [...] I was really hurt by this, that this is all they see in me.

Another woman told me how tensions regarding the way she dressed brought her to realize that she is no longer part of the community.

I met with the education committee and the village Rebbetzin (rabbi's wife). [...] They started preaching to me about modest dressing. They told me: "You must understand, when people see you like this it shatters their dream. People came here because they want to live in a certain place. It's like a man will wear a skirt, it's strange.” [...] Until then, I didn't think

\footnotetext{
${ }^{28}$ Bnei-Akiva is the largest religious-Zionist youth movement. Counselors are high school age.

${ }^{29}$ Most Jewish Orthodox communities consider wearing pants immodest, and women are expected to wear long skirts (the acceptable length varies).
} 
that there is anything wrong with the way I dressed, so now I need to think about this?! The way men view me? I understood that I don't belong. I'm outside of the line, and that sucks.

While they left their communities, and no longer feel obligated to Halacha, some Datlashim still seek a certain connection to Judaism, on their own terms. Some describe a spiritual connection to God and some admit they still partially observe Halacha, though they do not feel committed to adhering to every aspect of it. They feel free to pick and choose which commandments they want to follow. I asked one Datlash who expressed this ambivalent feeling if he considers himself religious. "I'm Jewish, brother," he said smiling. When I asked if he sees himself becoming religious again in the future he replied:

I'll tell you what it is. I like the religion, not the religious people. That's the problem. I try. I put up Mezurot ${ }^{30}$ in my house, I wear Tefilin ${ }^{31}$ when I feel like it, not every day. Sometimes I recite the "Shema" before I go to bed. ${ }^{32}$ Sabbath is still difficult. [...] I will eat in a nonkosher restaurant, but I will not eat a cheeseburger. I never ate shrimp. ${ }^{33}$ But my house is Kosher in case my brother or father will want to come over.

While none of the Datlashim expressed commitment to Halacha, most of them still identified with the Zionist nationalist ideology they grew up in. Politically, they tend to identify with right-wing and even religious parties, and most of them are still committed to the idea of the sacredness of the land of Israel:

I think I can never get "The Land of Israel” out of my system. I don't know if I want to or not. Everything about it thrills me, excites me. It got to a point that I said "enough! I don't want to feel this way anymore!" I always say that the Land of Israel is the actual (religiousZionist) religion. That is the big thing. God. [...] Last year I started college. Academia is the biggest lie there is, and it drives me crazy that I'm a part of it. [...] It is so leftist! They tell you to "think outside the box," but what they really mean is "think inside our box." [...] This whole thing was a shock to me because in my own village I am the one called "the leftist" [...] I am studying this course on the history of the Middle-East, the lecturer is Arab. She showed us a film on the War of Independence from the Arab point of view. A lot of shooting, IDF soldiers constantly killing Arabs. I didn't know what to do, at some point I couldn't stay. I left the classroom.

These findings suggest that we must reconsider our understanding of the centrality of Halacha in the national-religious sector. As I have shown, even within the Hardal society rabbis' rulings on public and political matters are not considered binding. Some may choose to follow their public rulings, but the society (and rabbis themselves) do not perceive this as an obligation. Even with regard to the interpretation of Halacha, where they do have authority, their interpretation is considered binding only when explicitly asked to provide a ruling. Also, there is a significant population that grew up

\footnotetext{
${ }^{30}$ Orthodox Jews interpret Jewish law to require a piece of parchment with verses from Deuteronomy to be placed on every doorstep in the house (except bathrooms).

${ }^{31}$ A pair of small black leather boxes containing scrolls of parchment inscribed with verses from the Torah. Orthodox Jews see high importance in wearing these every weekday morning during prayer.

32 A verse from Deutronomy 6:4-9, which is recited by Orthodox Jews three times a day: During morning prayer, evening prayer, and before going to bed.

${ }^{33}$ Shrimp and cheeseburger are forbidden foods for Jews who only eat Kosher.
} 
within the national-religious education system that does not feel committed to Halacha whatsoever. They do not define themselves as religious but stay within the national-religious sphere of influence. They still hold to many aspects of the value system they grew up on and identify with the right-wing political camp.

\section{Conclusion}

The religiosity of religious-Zionist settlers in the Halutza Sands provides a complex image of adherence to religion in contemporary Israel. Scholars of the Israeli society are concerned by the 'religionization' of many domains in the Israeli society, fearing their eventual subjection to religious authority. However, my research demonstrates that even the most conservative segments of the Israeli religious-Zionist community do not necessarily accept religious authority unquestioningly. On the contrary, they partially accept the normative premises of secularization theory and confine religious authority to matters strictly related to Halacha. They will consider religious reasoning on public matters, but in no way will accept it as binding.

At the same time, the fact that religious authority is in decline does not mean that religion is in decline altogether. As Euthyphro's dilemma teaches us, there are two ways in which we can understand religion. Instead of interpreting religion as blindly following religious authority, Euthyphro's dilemma shows us that also individuals and societies have the power of constructing what religion is. The individuals I interviewed for this article believe that their religion requires them to have an independent mind and think for themselves. Even the supposed dissenters, the Datlsabim, are still connected to the Jewish religion, despite their complete disregard for formal religious authority.

Despite the predictions of secularization theory, religion is a stronger force than ever worldwide, whether these are formal traditional forms of religion or 'new age' spiritualities. This article offers a contribution to making sense of this phenomenon through the study and understanding of the contemporary religious-Zionist community in Israel. As this article demonstrates, understanding religious authority, dissent, and the self-perception of believers is crucial in the study of religion. This analysis of the different understanding of what constitutes 'religion' can be applied in various cases globally, and will hopefully contribute to the future international study of religion.

\section{Acknowledgments}

The author wishes to thank the residents of Naveh, Bnei-Netzarim, and Shlomit for their openness and willingness to participate in this study. The author also wishes to thank Joel Migdal, Liora Halperin, Jim Wellman, and Christian Novetzke for their insightful comments on earlier drafts of this article. Finally, this research could not have happened without the generous financial support of the Stroum Center for Jewish Studies at the University of Washington, Seattle; and the Grizzley garage in Moshav Dekel, Israel.

\section{References}

Abulof, U. (2014). The Roles of Religion in National Legitimation: Judaism and Zionism's Elusive Quest for Legitimacy. Journal for the Scientific Study of Religion, 53(3), 515-533.

Asad, T. (1993). Genealogies of Religion: Discipline and Reasons of Power in Christianity and Islam. Baltimore: Johns Hopkins University Press.

Beit Hillel. (2014). Results of The Big Religious-Zionist Survey. Jerusalem: Beit Hillel. (Hebrew). 
164 New Religious-Nationalist Trends among Jewish Settlers in the Halutza Sands

Ben-Porat, G. (2013). Between state and synagogue: The secularization of contemporary Israel (No. 42). Cambridge University Press.

Brown, Benjamin. (2005) "The Doctrine of Daat Torah: Three Stages." In: Amir, Y. (Ed.): The Path of the Spirit: the Eliezer Schweid Jubilee: Volume two. Jerusalem: Van-Leer Institute. 537-600.

Butler, J., Habermas, J., Taylor, C., \& West, C. (2011). The power of religion in the public sphere. Columbia University Press.

Casanova, J. (2011). Public religions in the modern world. University of Chicago Press.

Chaves, M. (1994). Secularization as declining religious authority. Social forces, 72(3), 749-774.

Durkheim, E. (1915). The Elementary Forms of the Religious Life: A study in religious sociology. London: New York: G. Allen \& Unwin; Macmillan.

E, Elisha. (2003). National Planning and Development in Israel in the $21^{\text {st }}$ Century. Tel-Aviv: Ramot - Tel Aviv University. (Hebrew).

Gal-Getz-P. (2011) Hadatlashim. Tel-Aviv: Am-Oved.

Hellinger, M., Hershkowitz, I., \& Susser, B. (2018). Religious Zionism and the Settlement Project: Ideology, Politics, and Civil Disobedience. New York: SUNY Press.

Herman, T., Be'ery, G., Heller, E., Cohen, C., Lebel, Y., Mozes, H., \& Neuman, K. (2014). The national-religious sector in Israel 2014. Main Findings. Jerusalem: Israel Democracy Institute.

Israel Studies Review (2012) “The 'Religionization’ of Israeli Society,” 27 (1): v-208.

Katsman, H. (2020). The Hyphen Cannot Hold: Contemporary Trends in Religious-Zionism. Israel Studies Review. 35(2).

Katsman, H. and Ben-Porat, G. (2019). “Israel: Religion and Political Parties.” In: Haynes, J. (Ed.): Routledge Handbook of Religion and Political Parties. Abingdon, Oxon: Routledge.

Kimmerling, B. (2001). The Invention and Decline of Israeliness: State, Society, and the Military. Berkeley: University of California Press.

Klein, M. (2006). The Geneva Initiative: An Inside View. Jerusalem: Carmel.

Levy, Y. (2014). The theocratization of the Israeli military. Armed Forces \& Society, 40(2), 269-294.

Levy, Y. (2015). The Divine Commander: The Theocratization of the Israeli Military. Tel Aviv: Am Oved and Sapir Academic College. (Hebrew).

Liebman, C. S., Libman, Y., \& Don-Yihya, E. (1983). Civil religion in Israel: Traditional Judaism and political culture in the Jewish state. Univ of California Press.

Mahmood, S. (2005). Politics of Piety: The Islamic Revival and the Feminist Subject. Princeton, N.J.: Princeton University Press.

Maniv, O., \& Benziman, Y. (2020). National-Religionization (and not Religious-Religionization) in Policies of Israel's Ministry of Education. Israel Studies, 25(2), 115-137.

Newman, D. (1984). The Development of the Yishuv Kehilati in Judea and Samaria: Political Process and Settlement form. Tijdschrift voor economische en sociale geografie, 75(2), 140-150. https://onlinelibrary.wiley.com/doi/abs/10.1111/j.1467-9663.1984.tb00984.x

Pfefer, A. (2007). The Origins and Future Course of the National-Haredi Public. Jerusalem: The Floersheimer Institute for Policy Studies. 
Peled, Y. and Herman-Peled, H. (2019). The religionization of Israeli society. Abingdon, Oxon: Routledge.

Rosner, S. \& Fuchs, C. (2018). \#IsraeliJudaism, a Cultural Revolution. Israel: Kineret Zmora-Bitan, Dvir.

Roth, Anat. (2014) Not at any Cost: From Gush Katif to Amona: The Story behind the Struggle over the Land of Israel, TelAviv: Yediot Aharonot. (Hebrew)

Sofer, M., \& Applebaum, L. (2006). The rural space in Israel in search of renewed identity: The case of the moshav. Journal of Rural Studies, 22(3), 323-336. 